Contents lists available at \ournal IICET

JPPI (Jurnal Penelitian Pendidikan Indonesia)

ISSN: 2502-8103 (Print) ISSN: 2477-8524 (Electronic)

\title{
Development of ISTP (Indonesian Student Test Platform) evaluation tool to analyze student competency
}

\author{
Irbah Khairunnisa ${ }^{1}$, Dewie Tri Wijayanti ${ }^{2}$, Tri Sudarwanto ${ }^{3}$ \\ ${ }^{123}$ Universitas Negeri Surabaya
}

\begin{tabular}{l} 
Article Info \\
\hline Article history: \\
Received Feb $08^{\text {th }}, 2020$ \\
Revised May $21^{\text {th }}, 2020$ \\
Accepted Jun $23^{\text {th }}, 2020$
\end{tabular}

\section{Keyword:}

ISTP

Evaluation tool ICT

\begin{abstract}
ISTP is a website platform designed and developed to provide evaluation services and quiz online. Through the program site, teachers and students are expected to adapt to the test method switching and value recapitulation from the Manual (offline) method to the digital (online) method. This website can be used easily by both teachers and learners. The purpose of this research is to obtain a description of 1) product development in the form of Evaluation of ISTP, 2) Feasibility evaluation tool (Indonesian Student Test Platform) through the process of study and validation Experts, 3) The response of learners as a user to the assessment tool of ISTP that has been tested. The research development applied Thiagarajan's 4-D model. It is start from the definition stage to the development stage. The study is test on the 24 students. The research instruments were the questionnaire of material review and media, the material and media validity sheet, and the questionnaire of students' responses. The result of study suggest that the ISTP is very feasible. Therefore, it can be concluded that the ISTP is effectively applied as an alternative evaluation tool in senior high school.
\end{abstract}

(C) 2020 The Authors. Published by IICET

This is an open access article under the CC BY-NC-SA license (https://creativecommons.org/licenses/by-nc-sa/4.0

\section{Corresponding Author:}

Irbah Khairunnisa,

Universitas Negeri Surabaya

Email: irbah.17070925010@mhs.unesa.ac.id

\section{Introduction}

In the 21st century the presence and development of technology increasingly favored by the people in Indonesia. It is characterized by the abundance of human work involving technology from easy levels to complicated levels. Technology has entered and become culture in all walks of life so that they are inseparable, this is a consequence that must be received for the sophistication of science and technology known as the era of Revolution 4.0. The advent of the 4.0 revolution resulted in technology being a base in human life so that the awareness of modern society would be the importance of technology to help their activities rapid and competitive change from all areas (Hasniyati, 2018). The technological development of the 4.0 revolutionary era has affected many aspects of life in both social, economic, political, cultural and educational areas.

Today, the world of education is faced with the 4.0 Revolution era that integrates between digitization, optimization, adaptation, data automation, information provision and human-machine interaction (Martikasari, 2018:181). Until the 4.0 Revolution era demanded that Indonesian education be prepared to follow the technological developments in order not to experience disruption education where technology could threaten existence of teachers in carrying out their duties. In order not to shift functions by technological developments, the world of education needs to utilize technology and innovate learning by integrating media 
and learning evaluation with information communication Technologi ( ICT). Thus, the teaching methods conducted by the teacher become more innovative and interesting so that they can hone and develop students ' talents and change the learning model according to the needs of the Times (Saepudin, N. D).

One form of innovation in learning with integrating information comunication and technology (ICT) is by developing and using interactive learning media in learning. Many interactive learning media integrating information comunication and technology (ICT)-based websites are successfully developed and used in education, including e-learning or learning through online portals such as " Rumah Belajar KEMDIKBUD" and " Ruang Guru ", reading book site and encyclopedia are" Wikipedia, "Goodreads" and "Google book" and interactive visual Learning Media "inibudi.org".

In addition to learning media, evaluation tools have a role It is important to know the achievement of competencies that have been mastered by learners. That way, after the process Teacher Learning has an obligation to conduct a learning evaluation that not only serves as a deciding tool to assess a value but to find the cause of the failure and find a solution to improve on learning Next (Suprayitno, 2019). Unlike the learning media, the development ICT-based Evaluation Tool (website) as a test tool to measure the competencies that the learners have is still rarely used although currently, the online evaluation tool has been used as a determining test tool that is the implementation of national exams. The use of tools online evaluation as a tool to measure the competence of learners because the online based evaluation tool available and commonly used in Indonesia today has a slight weakness in the function of versatility.

The following are some of the general evaluation tools Used to measure the competence of students including, (1) "Quipper" The practice site, but the portal is not only focused on the practice alone but the majority contain the media learning in the form of interactive video, in addition there is a fee that must be issued to get all videos and exercises; (2) PTO (Education Tryout Online) This site displays the simulation view of UNBK so that the learners are familiar with the use of technology as well as calculation of UNBK values, but this site has a weakness where teachers who want to register or registration should get confirmation from the PTO team first, in addition if the teacher wants to do the input must go through 3rd party (team PTO) with how to send the problem on PTO team and then the PTO team will put the problem and set the time. Such a system is impractical and efficient in terms of time; (3) "KAHOOT" is a platform provider site that can be used for online evaluation. Kahoot is the most beloved site in conducting online evaluation in Indonesia, in addition to its attractive appearance that teachers can input the question in a practical way than other similar sites or platforms. But Kahoot also has several disadvantages where the multiple choice option is only a symbol (symbols) in the form of the possibility of cheating (cheat) done by the students. Based on the weaknesses of the evaluation tools that have been displayed, causes some teachers to re-use the writing and oral evaluation tools as they are considered the data management time equally take a long time.

To overcome the demands of the 4.0 technology era and avoid disruption education then the need to develop an ICT-based evaluation tool that can be used in a flexible, both for postest, pretest, daily replay and quiz with a detailed end result in the form of reports and immediate test feedback/Eazy grading is the results of the exam can be known directly by teachers and students after the exam is completed, so it can analyze the competence of learners in the economic lessons in real time or directly using the automatic input system of the database.

Development research was tested at SMA Negeri 1 Giri because based on the results of early observations conducted in November 2018, the school has a background that corresponds to the above problems, namely the condition of the school that has been equipped with adequate technological facilities and the problems faced by teachers in the learning process are not much. Note that the activity process evaluation of students in the school has not been computer based but verbal and written so as to obtain evaluation results takes a relatively long time, not yet fully objective and there is no transparency of judgment to learners. This is because ICT-based tests such as E-Xam, PTO (Education Tryout Online) and KAHOOT that have been used by teachers do not yet have a practical function that is not yet provided complete and detailed assessment reports to teachers and Students thus causing the teacher to still review and manually evaluate the test results that the learners have done.

According to the word Eka Saputra, S. Pd as a teacher of economic instruction in SMA Negeri 1 Giri, the use of ICT-based evaluation tools used so far is the same as writing evaluation system where teachers should spend more time correcting and reviewing Learners ' test results one by one so it is not efficient in terms of time. In addition, the writing and oral evaluation systems that have been used during this time have not been effective for measuring and analyzing the competence of learners in the cognitive, affective and psychomotor aspects. It is characterized by the learners who have a lack of good attitude in implementing evaluation of writing, so that teachers cannot know the ability of actual learners. At the time of oral evaluation, the ability of 
learners can be measured. The only drawback to the oral evaluation is the less scalable scoring system, which is likely to yield an objective value is low.

Expected with the development of ISTP evaluation tool (Indonesian Student Test Platform) by integrating ICT based on this website can analyse competence and increase the enthusiastic feelings of learners in carrying out tests or evaluation, improving discipline (thorough reading and Answer the question, Able to choose the right answer with the time provided and work on it according to self-ability), can improve the honesty of learners in answering the evaluation questions that have been given and know the level of mastery of learners To the material that has been taught and the difficulties it faces. In addition to the Development of Evaluation tool (Indonesian Student Test Platform) based on this website can help teachers to know the difficulties faced by learners so that it can be responsive to diagnose and give teaching remedial, can Assisting teachers in the effectiveness of technology use and time efficiency to correct and diagnose student weaknesses.

Online tests should have the advantages that learners and teachers can feel. The advantage that must be had in the online test for learners is to increase motivation, increase concentration and performance of learners (Mastuti,2016:12). While from the teacher aspect, online test utilization can help teachers reduce working time on the assessment process thus enabling teachers to act quickly in providing feedback to learners (Morera, 2012:39). In addition, some of the online evaluation functions by integrating ICT-based websites are: (1) Knowing the level of learners ' mastery of established competencies; (2) Knowing the difficulties experienced by learners in the learning process so that they can be diagnosed and targeted in providing remedial teaching; (3) Knowing the efficiency and effectiveness of the learning stratregi that teachers have used in the learning process. ICT or online based evaluation tools have a positive impact on learners to teach the responsibilities of for their own learning, so that learners can see if they have remembered and understood the material they have been taught, encouraging students to focus on problem solving strategies (Cohen, 2016:2).

By realizing the reality as it has been described above, then in this study the author took the heading " "Development Of ISTP (Indonesian Student Test Platform) Evaluation Tool To Analyze Student Competency"

Starting point from the background that has been written then the authors formulate the following problems: (1) How to develop the evaluation tool ISTP (Indonesian Student Test Platform)?, (2) How is the feasibility of the assessment tool ISTP (Indonesian Student Test Platform) based on material expert validation and media expert validation?, (3) How are students ' responses to the development of the Indonesian Student Test Platform (ISTP) evaluation?

Based on the background and formulation of problems can be mentioned the objective of the research, among others, as follows: (1) develop a product in the form of Evaluation of ISTP (Indonesian Student Test Platform), (2) describing eligibility ISTP Evaluation Tool (Indonesian Student Test Platform) based on material expert validation and media expert validation, (3) describing student response to ISTP Evaluation tool (Indonesian Student Test Platform)

\section{Method}

The target in this research is to develop an ICT-based ISTP evaluation tool. The development of the ISTP Evaluation Tool is a series of processes undertaken to develop a new product innovation in the event of evaluation based on relevant theories. The development procedure of the ISTP evaluation Tool uses a 4-D model of research and development that was adapted into 4-P by Thiagarajan and Semmel (1974). The 4-D model is a common model used to develop and solve problems in the field of education. The research conducted by researchers is limited to the level of trial or 3D, namely the definition (define), design (design), and development (develop).

\section{Result and Discussion}

In the development of the ISTP evaluation tool starts from the definition of 5 steps that consist of: (1) Front end analysis, based on the analysis of the front end known that the use of technology as an evaluation tool is not effective while Ownership of technology supporting learning in the school is good, (2) Student analysis, this step aims to know the characteristics and condition of the students before the evaluation tool has been developed by researchers. Based on the student's analysis the result that the students characteristics on self-reliance, discipline and competitiveness in the test/evaluation are not good, (3) Analysis of assignments, at this stage researchers consult with teachers and experts in order to obtain good and decent material to be displayed on students, (4) The analysis of the concept, at this stage the researcher determines the appropriate 
and relevant material and a structure of evaluation tools developed. The material chosen to be objectively is an international trading material where the material has the same characteristics as the characteristic input menu of the problem in the assessment tool of the Indonesian Student Test Platform (ISTP) (teacher) has the option to make a question in the form of sentences or inserting images, 5) at the planning phase, researchers designed the ISTP evaluation tool (Indonesian Student Test Platform) as a solution to the problems found during the initial observation include: (1) designing the making of evaluation tools with some advantages that are not yet owned by other similar products, (2) elections Draft evaluation tool (Indonesian Student Test Platform) adapted to some characteristics related to the evaluation tool designed, Website ISTP (Indonesian Student Test Platform) designed to have the ease of use. The ISTP evaluation tool is equipped with guidance so that teachers and students as users can operate properly and there is no misuse of the function of evaluation tools.

Stage of development, phase of development is done by the way the design component becomes a real form to make the evaluation tool (Indonesian Student Test Platform) developed can be tested for its use and testing to know the response Learners as users.

This phase generates ISTP (Indonesian Student Test Platform) media using international trade materials. The feasibility of the evaluation and material (item of matter) in this study was measured and produced through study and validation by experts. The results of the study obtained from the experts are then revised by the researcher when there are changes or suggestions. So that the development of ISTP evaluation tool can be validated by experts so that it can be said to be used as the result of study and validation by experts.

The study Data was obtained through a study sheet filled by Dr. Lucky Rachmawati. S.E., M. Si as a material expert and lecturer at the Faculty of Economics, Surabaya State University. The specialist study was conducted to determine the accuracy of the selected material as well as the question items made for use in the ISTP evaluation tool.

Table 6. Comments and suggestions

\section{Comments and Suggestions Repair}

Still there are problems that are still unclear and the grammar that gives rise to the double meaning it is necessary to be addressed

Source: Data processed researchers (2019)

Based on comments and suggestions by the material experts, revisions are made to the problem. Improvements are presented in the following table:

Table 7. Study and revision of materials

\begin{tabular}{|l|l|}
\hline \multicolumn{1}{|c|}{ Description } \\
\hline Before & $\begin{array}{l}\text { Sektor industri Indonesia masih bergantung pada impor barang modal dan bahan baku industri untuk } \\
\text { keperluan produksinya. Padahal, penyelenggaraan MEA akan semakin mempermudah masuknya } \\
\text { berbagai produk yang berasal dari negara anggota ASEAN. Dampak negatif pada perekonomian } \\
\text { indonesia adalah ... }\end{array}$ \\
\hline After & $\begin{array}{l}\text { Sektor industri Indonesia masih bergantung pada impor barang modal dan bahan baku industri untuk } \\
\text { kerbagai produksinya. Pemberlakuan Masyarakat Ekonomi Asean (MEA) mempermudah masuknya } \\
\text { perekonomian Indonesia adalah ... }\end{array}$ \\
\hline
\end{tabular}

Media study Data (ISTP Evaluation tool) obtained through the study sheet filled by Muhammad Abdul Ghofur, S.E., M. Pd as a media expert and lecturer of the Faculty of Economics University of Surabaya. The study of media experts was conducted to determine the accuracy of the media display that has been developed.

Table 8. Comments and suggestions

\section{No Comments and Suggestions Repair}

1 Add a Start page to explain the product

2 Guidebooks made online instead of offline considering the evaluation tools developed in the form of online

3 Feedback on Learner

Source: Data processed researchers (2019) 
Based on comments and advice by material experts, a revision of the media (ISTP evaluation tool). Improvements are presented in the following table 9:

Table 9. Revision of the media (ISTP evaluation tool)

\begin{tabular}{ll}
\hline \multicolumn{1}{c}{ Before } & \multicolumn{1}{c}{ After } \\
\hline Home Page & $\begin{array}{l}\text { There is a menu that describes the product so users know } \\
\text { what type of product to use }\end{array}$ \\
\hline No product description. So it is less appealing to use & $\begin{array}{l}\text { The guide is attached to the online. Because the resulting } \\
\text { media is online }\end{array}$ \\
\hline Handbook & \\
\hline The handbook is printed using an 80gr art paper. & $\begin{array}{l}\text { There is a feedback can be received by students by to know } \\
\text { the total score, correct and wrong number and rank earned }\end{array}$ \\
\hline $\begin{array}{l}\text { Aeedback on Learners } \\
\text { the learners will be logged out automatically }\end{array}$ &
\end{tabular}

After the media has been studied and remark, subsequent media are in validation by experts to obtain the feasibility results of materials and media. The following are the results of material and media validation by experts:

Table 10. Results validation material expert

\begin{tabular}{l|c|c|c|c}
\hline \multicolumn{1}{c|}{ Variable } & Score validation & Score Max & $\%$ & Description \\
\hline Precision & 4 & 5 & 80 & Worth \\
\hline Interests & 5 & 5 & 100 & Very decent \\
\hline Completeness & 5 & 5 & 100 & Very decent \\
\hline Balance & 5 & 5 & 100 & Very decent \\
\hline Attention & 5 & 5 & 100 & Very decent \\
\hline Suitability & 5 & 5 & 100 & Very decent \\
\hline $\begin{array}{l}\text { R\% x 100\% x 100\% } \\
96,6 \text { Very decent }\end{array}$ & & & & \\
\hline Source: Data processed researchers (2019) & & & &
\end{tabular}

Based on table 10 above, you can know that the presentations obtained from some of the material feasibility include; A) The precision component of the result of a qualifying percentage of $80 \%$ so that it can be classified into a decent category, b) in the interest variable obtaining a score of $100 \%$ so that it can be categorized as feasible, c) completeness of obtaining percentage Of $100 \%$ with very decent category, d) the balance got a point of $100 \%$ with a category very decent, e) on the variable attention gets a percentage of $100 \%$ with a category is very decent and, f) suitability got percentage $100 \%$ with very decent category.

According to the result of media expert validation above obtained percentage of media validation results of the two variables that include: 1) The Instructional quality variable obtains a qualifying percentage of $86.6 \%$ with a highly viable category; 2 ) A technical quality variable of $83 \%$ with very decent categories. Both variables obtained an average value of $85 \%$ so that the evaluation tool ISTP (Indonesian Student Test Platform) is said to pass the feasibility test and can be used. 
Table 11. Results of Media Expert Validator

\begin{tabular}{|c|c|c|c|c|}
\hline Variable & Indicator & Score & $\%$ & Description \\
\hline \multirow[t]{6}{*}{ Instruction Quality } & 1 & 4 & 80 & Worth \\
\hline & 2 & 4 & 80 & Worth \\
\hline & 3 & 4 & 80 & Worth \\
\hline & 4 & 5 & 100 & Very decent \\
\hline & 5 & 4 & 80 & Worth \\
\hline & 6 & 5 & 100 & Very decent \\
\hline \multirow[t]{6}{*}{ Technical quality } & 7 & 4 & 80 & Worth \\
\hline & 8 & 4 & 80 & Worth \\
\hline & 9 & 5 & 100 & Very decent \\
\hline & 10 & 5 & 100 & Very decent \\
\hline & 11 & 4 & 80 & Worth \\
\hline & 12 & 3 & 60 & Decent enaugh \\
\hline
\end{tabular}

Table 12. Learners Response Results

\begin{tabular}{|c|c|c|c|c|}
\hline \multirow{2}{*}{ Indicator } & \multicolumn{2}{|c|}{ Answer options } & \multirow{2}{*}{$\%$} & \multirow{2}{*}{ Description } \\
\cline { 2 - 4 } $\mathbf{1}$ & Yes & No & \\
\hline $\mathbf{2}$ & 23 & 1 & 95,8 \\
\hline $\mathbf{3}$ & 22 & 2 & 91.6 \\
\hline $\mathbf{4}$ & 22 & 2 & 91.6 \\
\hline $\mathbf{5}$ & 22 & 2 & 91.6 \\
\hline $\mathbf{6}$ & 22 & 2 & 91.6 \\
\hline $\mathbf{7}$ & 22 & 2 & 91.6 \\
\hline $\mathbf{8}$ & 23 & 1 & 95,8 \\
\hline $\mathbf{9}$ & 23 & 1 & 95,8 \\
\hline $\mathbf{1 0}$ & 17 & 7 & 70.8 \\
\hline $\mathbf{1 1}$ & 20 & 4 & 83 \\
\hline
\end{tabular}

Source: Data processed researchers (2019)

Based on table 11 obtained percentage of student response results from 2 (two) variables that include; A) The Instructional quality variable obtains a qualifying percentage of $92 \%$ with a highly viable category, B) a technical quality variable of $89.5 \%$ with very decent categories. Both variables derive an average value of $90.8 \%$ in this way, the Indonesian Student Test Platform (ISTP) evaluation is getting a good response from the students.

Based on the research and analysis of data and discussion conducted on the development of Evaluation tool (Indonesian Student Test Platform), it can be concluded that:

\section{Development of ISTP Evaluation Tool}

Development of evaluation tools using Model 4-D from Thiagarajan consisting of 4 phases of definition (define), planning (design), stage of development (develop), and phase of dissemination (disseminate). But in this research, researchers only do research up to the 3rd stage. The development process includes the selection of materials, the selection of media formats, the arrangement of grain items that are studied and validated by experts.

The purpose of this media development is: (1) to assist teachers in choosing a simple alternative evaluation tool and has a detailed reporting system and can be used to analyze the competencies of learners with a short time and Can generate objective assessments in real time. The purpose of the research in accordance with the purpose of the utilization of online evaluation presented by Morera is to help teachers reduce work 
time on the assessment process so as to enable the teacher to act quickly in providing feedback to Learners (Morera, 2012:39); (2) can help train independence and discipline in the test or evaluation, and improve competitiveness. The purpose is in accordance with the purpose of the assessment of online evaluation by Mastuti that students can increase the motivation to learn to deepen understanding, improvethe concentration and performance of learners (Mastuti,2016:12).

\section{Description of eligibility for ISTP evaluation tool (Indonesian Student Test Platform)}

The feasibility of material and media experts on a developed ISTP evaluation tool is measured by the validation of material and media experts. Based on the assessment results, the ISTP Evaluation tool (Indonesia Student Test Platform) is well-deserved as it meets the aspects of accuracy, importance, completeness, balance, interests and suitability.As stated by Arsyad (2011:175) that the media is said to be worthy if it meets the quality of content and purpose, interests, completeness, balance, interest or suitability. The material in the evaluation tool deserves use when it gets the validation value Of $61 \%$ to $80 \%$. Based on the scoring criteria via Linkert scale, the recapitulation of the value of $81 \%$ to $100 \%$ can be categorized as feasible (Riduwan,2016:15). Based on material validation by the material specialists acquired a $96 \%$ qualification percentage which is declared highly feasible and based on the validation of the evaluation tool obtained a percentage of $85 \%$ which is stated very feasible so that the ISTP evaluation tool can is said to be valid or very worthy

\section{Description of students ' response to the Assessment tool ISTP (Indonesian Student Test Platform)}

The results of the student's response to the use of the evaluation tool that has been developed is a positive evidenced by the average response poll value of $91.6 \%$ which can be declared very decent. During the evaluation the students are shown a positive attitude, making it possible to improve the standards of the students ' quality, but not the standards of the student's value. If learners do not have a mature preparation of the test material, the standard of quality improvement and standard of value will not be fulfilled. At the time of evaluation, students ' weaknesses in certain materials or indicators will be carried out with a detailed and objective assessment system so that they can make it easier for teachers to design future learning activities.

\section{Conclussion}

Development of evaluation tools using Model 4-D from Thiagarajan consists of 4 defining phases (define), planning (design), stage of development (develop), and stage of dissemination (dessiminate). However, the research researchers only did research until the 3rd stage. The development process includes the selection of materials, the selection of media formats, the arrangement of grain items that are studied and validated by experts. Based on the results of the assessment conducted by the expert, the ISTP evaluation tool (Indonesia Student Test Platform) is well-deserved because it meets the aspects of accuracy, importance, completeness, balance, interests, and conformity. As stated by Arsyad (2011:175) that the media is said to be worthy when fulfilling the quality of content and objectives, Of interest, completeness, balance, interest or suitability. The material in the evaluation tool is worth using when it gets a validation value of $61 \%$ to $80 \%$. Based on the scoring criteria via Linkert scale, the recapitulation of the value of $81 \%$ to $100 \%$ can be categorized as feasible (Riduwan,2016:15). Based on material validation by material members acquired the percentage of eligibility of $96 \%$ which is stated to be very decent and based on the validation of evaluation tools obtained a percentage of $85 \%$ which is declared very feasible so ISTP evaluation tool can be said to be valid or very worthy. The results of the learners ' response to the use of the evaluation tool is a positive evidenced by the average response rate of $91.6 \%$ which can be expressed very decent. During the evaluation the students are shown a positive attitude, making it possible to improve the standards of the students ' quality, but not the standards of the student's value. If learners do not have a mature preparation of the test material, the standard of quality improvement and standard of value will not be fulfilled.

\section{References}

Arsyad, A. (2011). Media Pembelajaran.. Jakarta : Rajawali Perss .

Donita Cohen, I. S. (2016). Online Quizzes In A Virtual Learning Enviroment As A Tool For Formative Assesment. Journal Of Technology and Science Education, http://www.jotse.org/index.php/jo tse/article/view/217/225.

Hasniyati, S. (2018, September 26). Menghadapi Revolusi Industri 4.0 Dengan Rumah Belajar. Diambil kembali dari Pena Belajar Kemdikbud: http://pena.belajar.kemdikbud.go.id/2018/09/menghadapirevolusiindustri-4-0-dengan-rumah-belajar

Manalu, H. M. (2013). Peranan Teknologi Informasi Dalam Perkembangan Dunia Bisnis di Indonesia. TeIKa Portal Garuda, 4(2) 45-54. 
Martikasari, K. (2018). Kahoot : Media Pembelajaran Interaktif Dalam Era Revolusi Industri 4.0. Prosiding Seminar Nasional FKIP 2018. Yogyakarta: http://usd.ac.id/snfkip2018.

Mastuti, E. (2016). Pemanfaatan Teknologi Dalam Menyusun Evaluasi Hasil Belajar : Kelebihan dan Kelemahan Tes Online Untuk Mengukur Hasil Belajar Mahasiswa. Jurnal Penelitian Psikologi Unair, 7(1) $10-19$.

Morera, A. A. (2012). Analysis Of Online Quizzes As a teaching And Assesment Tool. JOTSE Journal, 2(1) 39-45.

Riduwan. (2016). Skala Pengukuran Variabel- Variabel Penelitian. Bandung: Alfabeta.

Saepudin, B. (t.thn.). Revolusi Industri 4.0 dan Pengaruhnya Terhadap Pendidikan. Diambil kembali dari disdikkbb.org: http://disdikkbb.org/?news=revolu si-industri-4-0-apakah-itu-dan- pengaruhnya-terhadapdunia- pendidikan

Suprayitno, T. (2019). Menggagas Sistem Pendidikan Indoneisa Masa Depan. Kuliah Umum Pascasarjana Universitas Negeri Surabaya. Surabaya 